DE GRUYter DOI: 10.1515/plass-2016-0004

Seyyed Mohammad Ali Kargar, Saba Jahan Kareh

Department of Agronomy and Plant Breeding, Islamic Azad University, Kermanshah Branch, Iran; Coresponding Author’s e-mail: Sma.Kargar@gmail.com

\title{
THE EVALUATION OF SEED GERMINATION ON 12 SOYBEAN CULTIVARS UNDER DIFFERENT SALINITY STRESS LEVELS
}

\begin{abstract}
In order to study effects of saline water on seed germination of various soybean cultivars, an experiment was conducted using completely randomized design with factorial method and three replications in 2012.

The factors were salinity stress levels (A) $(0,30,60$ and 90) $\mathrm{mM} \mathrm{NaCl}$, soybean cultivars (B) (Including 12 seed cultivars of II and III maturity groups). Five traits including seed germination, seed vigor, dry weight of radical and, plumule and biologic yield were studied. The results of analysis of variance showed significant differences between cultivars on studied traits at $1 \%$ level of significance. The highest biologic yield belonged to Hy-1 and Steel under $90 \mathrm{mM}$. It was belong to M9, Clark and Union under $60 \mathrm{mM}$ and belonged to Hy-1, Halcor and Union under $30 \mathrm{mM}$.

The results of comparison means using Duncan's method showed L17 and Steel not only had the high seed germination and vigor but also they had dry weight of radicles and biologic yield than others. It was identified although Union, Elgine and Williams were in second grade on seed germination and vigor but they had considerable growth and dry weight. Based on display scatter plot with two STI and GMP indices, L17 and Elgine were placed in A region of plot under $30 \mathrm{mM} \mathrm{NaCl}$, while they were in B region under 60 and $90 \mathrm{mM}$ salinity stress. The cultivars such as Union and Hy-1 were in $\mathrm{C}$ region of mentioned scatter plot.
\end{abstract}

Key words: environmental stress, saline water, seed characters, soybean

Abbreviation: $\quad$ STI (Stress Tolerance Index), GMP (Geometric Mean Production)

\section{INTRODUCTION:}

The soybean (US) or soya bean (UK, AU) (Glycine max L.) is a species of legume that growing in East Asia. This plant is classified as an oilseed (FAO). Stress is

Communicated by Grzegorz Żurek 
non-ordinarily phenomenon in physiological process that it is occur of combination of biologic and environmental effects (Levitt, 1980). Salinity is one of factors which damages to cell plants and inhibits of growing them. Its damage is due to different type of oxygen activation radicals that toxic and activator for their cells (Jiang and Zha, 2001). It is one of factors so that decrease legumes yields in arid and semi arid zone. It is estimated about 340 million hectares of farm lands were faced with salinity (Arzani, 2001). Based on the United Nations Environment Programs, It was estimated that approximately $20 \%$ of agricultural lands and $50 \%$ of croplands were settled in salinity regions in the world (Flowers and Yeo, 1995). Soil salinity is a major constraint to food production because it limits crop yield and restricts use of land previously uncultivated (Shuji Yokoi et al, 2002). The most ions of saline soils are $\mathrm{Na}+$ and $\mathrm{Cl}$ - that affects on cell membrane via interaction competition and selectable ion penetration and disorder on absorption macro and micro elements (Francisco et al., 2002; Grattan and Grieve, 1992). The extensive genetic diversity for salt tolerance was studied on plant taxa and distributed on other numerous genera (Flowers et al., 1986; Greenway and Munns, 1980). The plant response to salinity are consists of many processes such as cellular hyper osmolarity and ion disequilibrium that must be function in coordination to salinity effects. Plant responses are either avoiding or tolerating to salt stress. The plants are either dormant during the salt episode or they must be adjust their cells to tolerate the salinity effects (Bohnert et al., 1995). Salinity stress effect on soybean via toxicity of $\mathrm{Cl}$ - than $\mathrm{Na}+$. The susceptibility of seedling soybeans in Glycin max L. is more than Glycin soja and salinity decreased chlorophyll, photo synthesis and assimilation in soybean (Luo et al., 2005). It was reported that root hairs were wrinkled under increasing salt. The elasticity of root hairs was decreased under $1 \% \mathrm{NaCl}$ density and they were wrinkled under $1.5 \%$ of salinity condition (Zahran and Sprent, 1986). Dry mass of root and stem of soybean was decreased under $80 \mathrm{mili} / \mathrm{mol} \mathrm{NaCl}$ and it was lass in tolerant cultivars than others (Velagaleti et al., 1990). Based on reports dry mass of whole bush was decreased under salinity (Ikeda, 1994; Wang and Shannon, 1999; Basra and Basra, 1997). Salinity is known for its depressing effects on germination percentage, length of shoot and root, fresh and dry weight of shoot and root. Its effects are either completely inhibits germination at higher levels or induces a state of dormancy at lower levels (Khan and Ungar, 1997). In a research, the effects of salinity on six soybean cultivars on germination stage under. $0,3,6,9$, 12 and $15 \mathrm{dS} \times \mathrm{m}^{-1} \mathrm{NaCl}$ were examined. The results showed that soybean cultivars significantly varied in averages of final germination percentage, mean germination time, germination index, vigor index and energy of germination. Results showed that germination percentage, germination index, and seedling vigor index were decreased under salinity levels from 0 to $15 \mathrm{dS} \times \mathrm{m}^{-1}$ significantly (Kandil et al., 2015). Khajeh-Hosseini et al. (2002) reported that salinity had negative effects on germination characters. Germination decreased under Nacl concentration of 330 $\mathrm{mM} \mathrm{Nacl}(81 \%$ germination) while above at $420 \mathrm{mM} \mathrm{NaCl}$, it is only $40 \%$ and at $500 \mathrm{mM} \mathrm{NaCl}$ there was no germination. Based on this study, soybean seeds were 
more tolerance to salinity during germination than in the seedling phase. Ahmadvand et al. (2012) reported that increasing salinity levels from 0 , 4, to $8 \mathrm{dS} \times \mathrm{m}^{-1}$ lead to decreasing final germination percentage. Seed vigor includes all of the characters that can cause to rapid and uniform seedling emergence under wide range of environmental condition after seed planting (Copeland and $\mathrm{Mc}$ Donald, 1985). Based on reports, Seed size is one of the important yield components which has effect role on cultivar adaptation to different environmental condition. It is effective on seed vigor (Morrison and Xue, 2007). Tobe et al. (1999) reported the derived toxicity of saline water is a cause for decreasing radicle in various plant spicies. Ten sesame cultivars were examined under $\left(0,5.3,8.5,12.05,14.65\right.$ and $\left.18.45 \mathrm{dS} \times \mathrm{m}^{-1}\right)$ of salinity and it was resulted germination and seedling growth were strongly inhibited under $12.05 \mathrm{dS} \times \mathrm{m}^{-1}$. ( Bahrami and Razmjoo, 2012).

The identification of the best cultivars about germination and the other seed characters and demonstration tolerant them under salinity stress levels and so identification the threshold of salinity tolerance in soybean in seedling stage were the objectives of this research.

\section{MATERIALS AND METHODS}

\section{Experimental design and treatments}

This experiment was conducted using completely randomized design with factorial method in seed technology laboratory of Islamic Azad University (Kermanshah branch) in 2012.A factor was included four salinity stress as $(0,30,60$ and 90$) \mathrm{mM} \mathrm{NaCl}$ and $\mathrm{B}$ factor included 12 seed cultivars of soybeans that belonged to II and III maturity group.

\section{The study method}

At the first, the seeds were disinfected with sodium hypochlorite $25 \%$ (containing $5 \%$ activated chloride), then they were treated in potassium nitrate soluble ( $2 \%$ in density) for raising dormancy. The bed cultures were filter paper that disinfected in sodium hypochlorite $25 \%$ (containing $5 \%$ activated chloride) under two stages washing with distilled water. They were placed in the Petri dishes with ten centimeter diameter that were disinfected at one hour under $120^{\circ}$ centigrade. The disinfected seeds were washed and cultivated into petri dishes. Each replication included 25 seeds.

The petri dishes were cited into germinator under $25^{\circ} \mathrm{C}$ (day) and $15^{\circ} \mathrm{C}$ (night) under treatment with 16/8 hours light/ darkness regime (ISTA Rules, 2013).

The cultivated seeds were irrigated with mentioned different saline water versus distilled water as (normal condition) each three days. 


\section{Evaluation of quantitative traits:}

The first counting seedling was the third day and final counting was at tenth day than cultivation time. For evaluation seedling growth and theirs radicles, the petris were irrigated for one week furthermore (17 days totally). After that, dry weight of radicles and (Plumules) were measured using digital balanced with 0.0001 gram accuracy. Total of them in each replication was recorded and their means was considered as biologic yield for each cultivar.

\section{Data analysis:}

The data were normalized and converted for analysis. The analysis of variance was conducted using completely randomized design with factorial method moreover the comparison means was conducted using Duncan's method at $1 \%$ level.

The percent of variation of traits was used for evaluation decrease and increasing of them. It was calculated with below formula. Two STI (Stress Tolerance Index) and GMP (Geometric Mean Production) indices were used for estimation amounts of tolerance of studied cultivars, (Fernandez,1992).

$$
\begin{gathered}
S T I=\left(\frac{Y_{p}}{\bar{Y}_{p}}\right) \times\left(\frac{Y_{s}}{\bar{Y}_{S}}\right) \times\left(\frac{\bar{Y}_{s}}{\bar{Y}_{p}}\right)=\frac{\left(Y_{p}\right) \times\left(Y_{s}\right)}{\bar{Y}_{p}^{2}} \\
G M P=\sqrt{Y_{s} \times Y_{p}}
\end{gathered}
$$

where:

$Y_{p}=$ yield of each cultivar under non-stress condition

$Y_{s}=$ yield of each cultivar under stress condition

$\bar{Y}_{p}$

${ }_{p}=$ Mean of total cultivars under normal condition

$\bar{Y}_{s}=$ Mean of total cultivars under stress condition

In this research, the software's such as SPSS (version 16), MSTAT-C (version 2.10) were used for analysis of recorded data and drawing scatter plots and Microsoft office (version 2007) (Excel environment) was used for drawing graphs.

\section{RESULTS}

Analysis of variance:

Based on analysis of variance of data, there were significant differences at $1 \%$ level between studied cultivars on five evaluated traits of them. In A factor (stress) the variation was significant only in dry weight of radicel at $5 \%$ level. It 
was reported that root hairs were wrinkled under increasing salt. The elasticity of root hairs was decreased under $1 \% \mathrm{NaCl}$ density and they were wrinkled under $1.5 \%$ of salinity condition (Zahran and Sprent, 1986). The lowest of coefficient of variation belonged to seed germination $(29.51 \%)$ while the highest belonged to dry weight of plumule (76.85\%) (as shown in Table 1)

Table 1

The results of analysis of variance on studied traits of 12 soybean cultivars under different salinity effects

\begin{tabular}{lcccccc}
\hline \multirow{2}{*}{ Source of variation } & $\begin{array}{c}\text { Degree of } \\
\text { freedom }\end{array}$ & $\begin{array}{c}\text { First count- } \\
\text { ing (Seed } \\
\text { vigor) }\end{array}$ & $\begin{array}{c}\text { Second } \\
\text { counting } \\
\text { (Seed germi- } \\
\text { nation) }\end{array}$ & $\begin{array}{c}\text { Radicle dry } \\
\text { weight }\end{array}$ & $\begin{array}{c}\text { Plumule dry } \\
\text { weight }\end{array}$ & $\begin{array}{c}\text { Biological } \\
\text { yield }\end{array}$ \\
\cline { 3 - 7 } (Stress) A & 3 & 161.496 & 282.852 & $0.004^{*}$ & 0.005 & 0.001 \\
(Cultivar) B & 11 & $1939.877^{* *}$ & $1251.424^{* *}$ & $0.005^{* *}$ & $0.013^{* *}$ & $0.006^{* * *}$ \\
AB & 33 & 96.263 & 129.236 & 0.001 & 0.001 & 0.001 \\
Error & 96 & 243.453 & 265.836 & 0.00129 & 0.0034 & 0.00193 \\
\hline Total & 143 & & & & & \\
Coefficient of variation [\%] & - & 31.72 & 29.51 & 26.19 & 76.85 & 26.25 \\
Max & & 75.66 & 76.50 & 31.68 & 19.04 & 42.43 \\
Min & & 26.66 & 38.16 & 11.44 & 1.02 & 16.9 \\
\hline
\end{tabular}

\section{The comparison of means:}

The results of comparison mean using Duncan's method at $1 \%$ level showed Baj-maj and Bonus with 75.67 and $63.17 \%$ had the highest seed vigor and LD9, L17, M9, Steel, Union and Williams had the amounts between 44.67 to $26.67 \%$ as the cultivars with the lowest of it. Seed vigor includes all of the characters that can cause to rapid and uniform seedling emergence under wide range of environmental condition after seed planting (Copeland and $\mathrm{Mc}$ Donald, 1985).

The cultivars including L17 and Steel with 75.63 and $63.17 \%$ had the highest seed germination while the cultivars such as Baj-maj, Hy-1, Union, Elgine, M9 and Bonus with 44.67 to $26.67 \%$ had the lowest in this trait (As showen in Table 2 and Fig. 1). The clutivars including Union, Elgine, Steel, Hy-1, L17 and LD9 had the highest dry weight of plumule between 138.3 to 69.54 mili gram. The others such as Steel, Hy-1, L17, LD9, Bonus, Baj-maj, Williams, M9, Halcor and Clark had the low amounts so that Clark had $1.02 \mathrm{mg}$ as the lowest. Based on comparison mean at $1 \%$ level, LD9, Williams, Halcor, Clark, Baj-maj and Elgine had the highest amount between 31.6 to $18.7 \mathrm{mg}$ in dry weight radical. The others including Clark, Baj-maj, Elgine, Union, LD9, Hy-1, Steel and Bonus had low amounts and M9 had the lowest as $11.4 \mathrm{mg}$ (as shown in Table 2). 


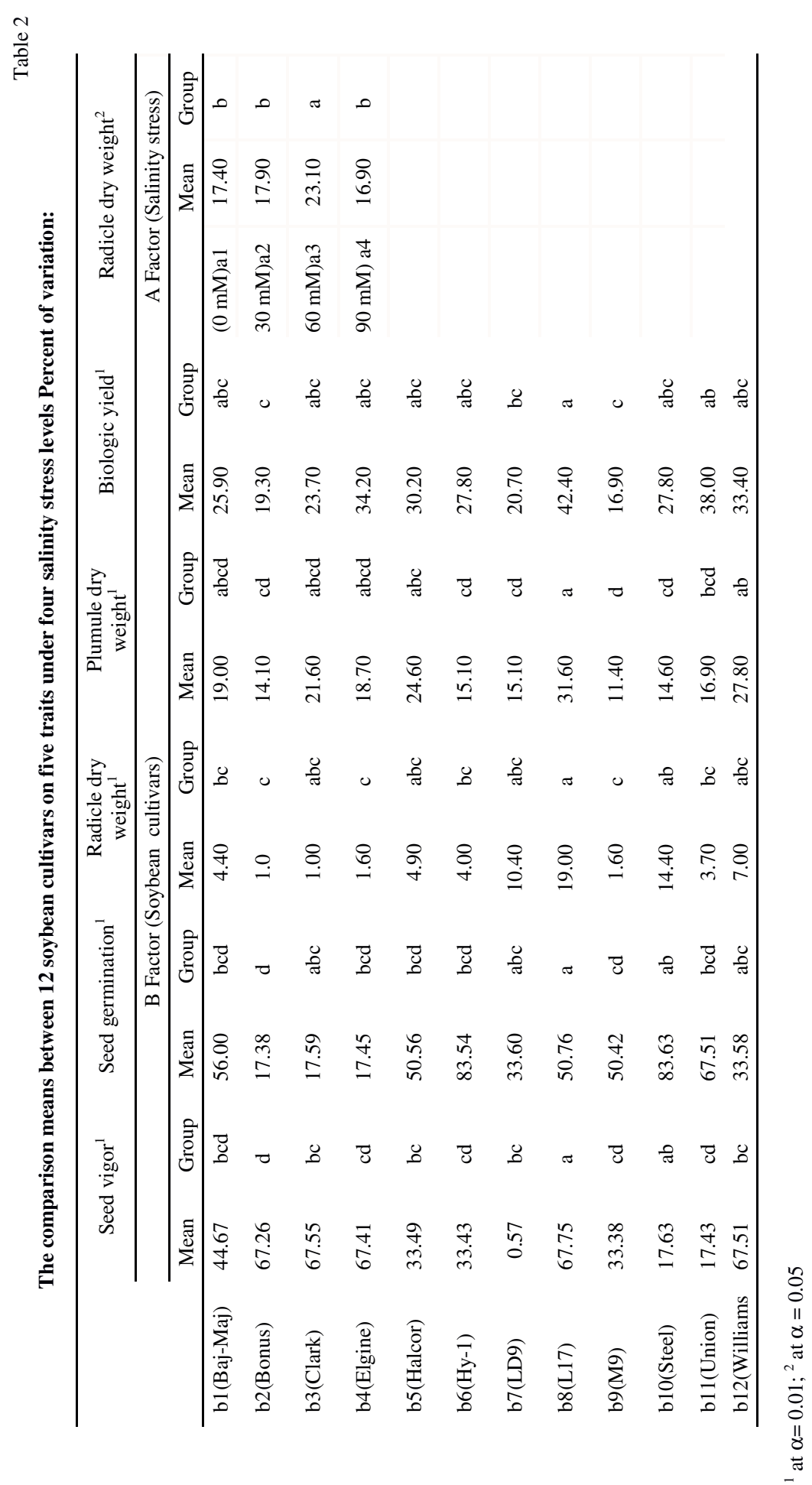




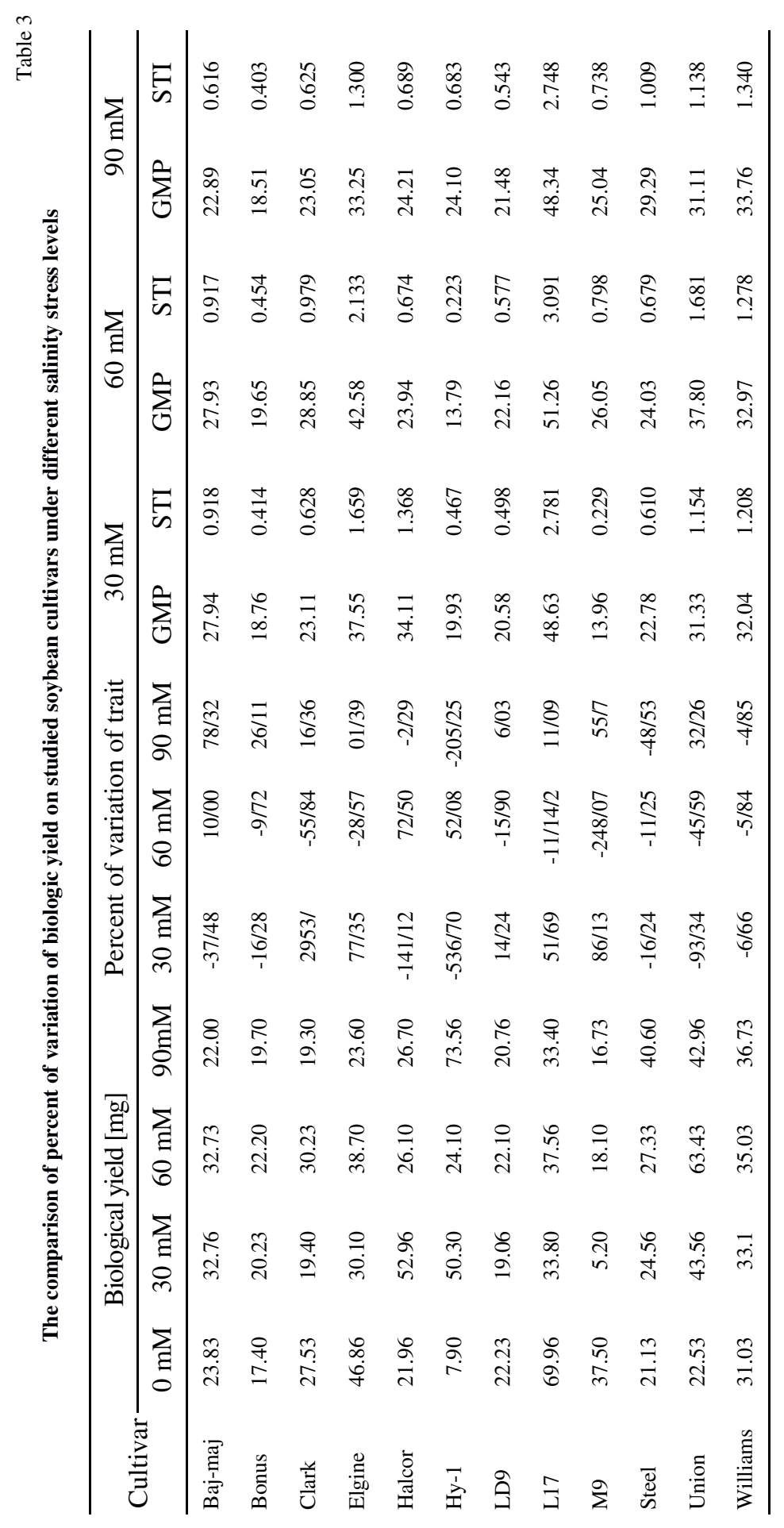




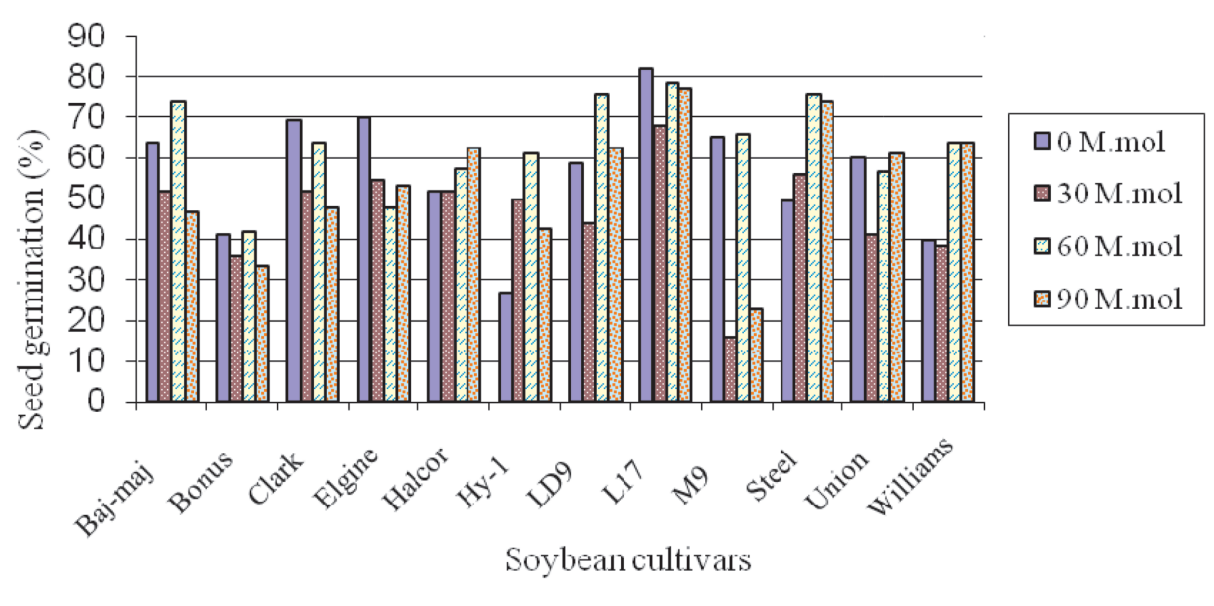

Fig. 1. The comparison of seed germination of 12 soybean cultivars under different salinity stresses

The cultivars including L17, Union, Elgine, Williams, Halcor, Steel, Hy-1, Baj-maj and Clark with the amounts between 42.4 to $23.7 \mathrm{mg}$ in biologic yield had the highest means. On the other hand, Elgine, Williams, Halcor, Steel , Hy-1, Baj-maj, Clark, LD9 and Bonus had low amounts and M9 had the lowest mean (as shown in Table 2).

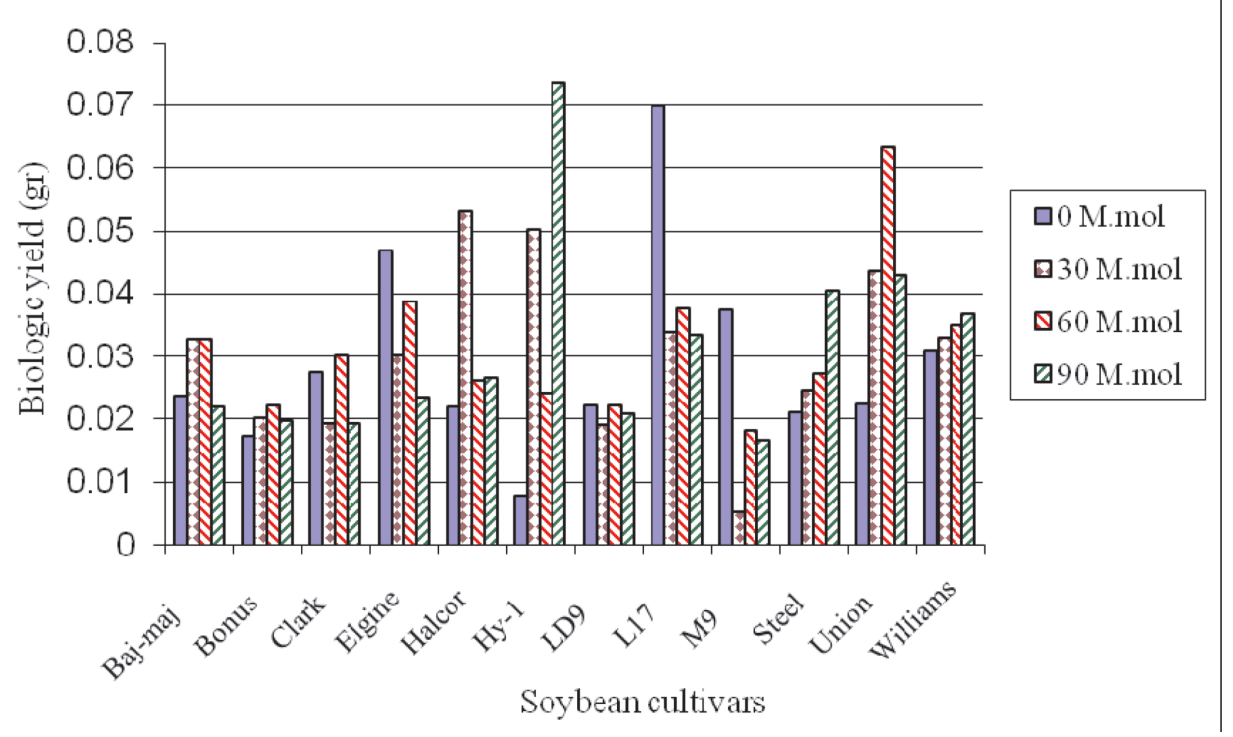

Fig. 2. The comparison of biological yield of 12 soybean cultivars under different salinity stresses

Based on percent of variation of biologic yield, Hy-1 and Union with 536.70 and $-93.34 \%$ had the lowest amounts under $30 \mathrm{mM}$ salinity. M9 and 
Clark had the lowest amounts -248.07 and $-55.84 \%$ under $60 \mathrm{mM}$ salinity. The cultivars including Hy-1 and Steel with -205.25 and $-48.53 \%$ in $90 \mathrm{mM}$ salinity condition (as shown in Table 3 and Fig. 2,3). In a research was reported that salinity decreased chlorophyll, photo synthesis and assimilation in soybean (Luo et al., 2005).

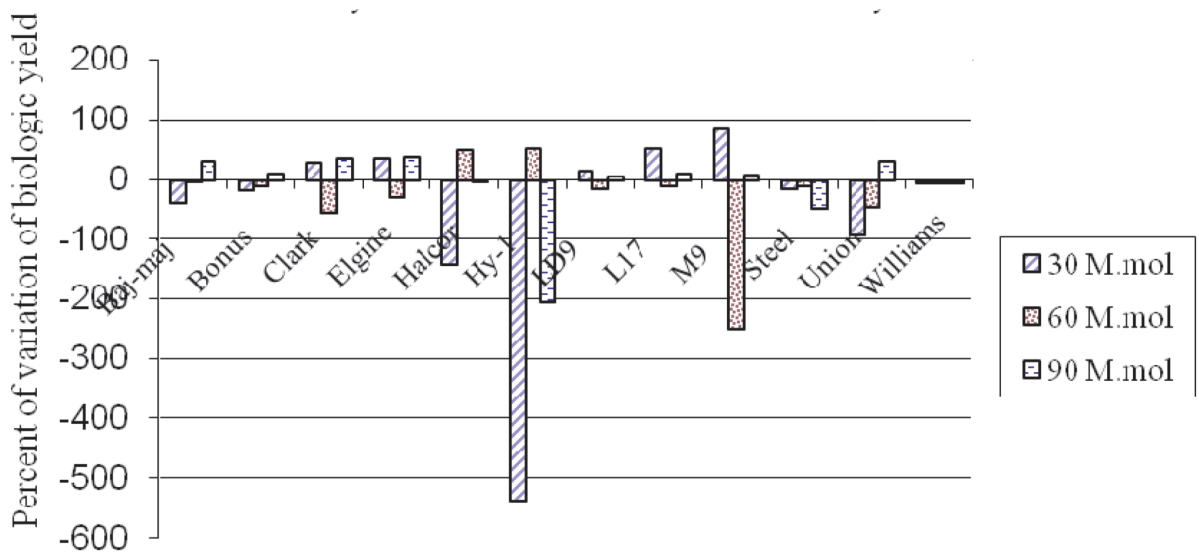

Soybean cultivars

Fig. 3. The comparison of biological yield variation percent of 12 soybean cultivars under different salinity stresse

Table 4

The comparison of percent of variation of studied traits under different salinity stress levels

\begin{tabular}{lccccccc}
\hline \multirow{2}{*}{ Parameters } & \multicolumn{3}{c}{ The mean of traits } & \multicolumn{4}{c}{ Percent of variation } \\
\cline { 2 - 8 } & $0 \mathrm{mM}$ & $30 \mathrm{mM}$ & $60 \mathrm{mM}$ & $90 \mathrm{mM}$ & $30 \mathrm{mM}$ & $60 \mathrm{mM}$ & $90 \mathrm{mM}$ \\
\hline $\begin{array}{l}\text { Seed vigor } \\
\begin{array}{l}\text { Seed germi- } \\
\text { nation }\end{array}\end{array}$ & 48.668 & 47.278 & 52.222 & 48.611 & 2.856086 & -7.30254 & 0.11712 \\
$\begin{array}{l}\text { Dry weight of } \\
\text { radicle }\end{array}$ & 17.424 & 17.956 & 23.104 & 16.900 & -3.05326 & -32.5987 & 3.007346 \\
$\begin{array}{l}\text { Dry weight of } \\
\text { plumule }\end{array}$ & 7.569 & 7.225 & 3.969 & 5.041 & 4.544854 & 47.56243 & 33.39939 \\
Biologic yield & 28.561 & 28.224 & 29.584 & 25.281 & 1.179931 & -3.58181 & 11.48419 \\
\hline
\end{tabular}

These results showed that the most of traits under $90 \mathrm{mM}$ were decreased while they had increasing under $60 \mathrm{mM}$ salinity. Dry weight of radical was increased under 30 and $60 \mathrm{mM}$ salinity as -3.053 and $-32.59 \%$ respectively. Seed vigor had only increasing under $60 \mathrm{mM}$ as $-7.30 \%$. Dry weight of plumule was the only trait decreasing under 60 and $90 \mathrm{mM}$ as 47.56 and 33.39 respectively (as shown in Table 4). 


\section{Environmental indices:}

In evaluation of the cultivars using the indices such as GMP and STI, two cultivars, including L17 and Elgine had the highest amounts under whole of salinity conditions and Williams had the response similar to Elgine only in 90 $\mathrm{mM}$ condition (as shown in Table 3 ).

\section{Scatter plot:}

Based on display scatter plot with GMP and STI, L17 was the only cultivar with high $Y_{p}$ and Ys under $30 \mathrm{mM}$ salinity and was cited in A region. After that elgine was cited in second grade, it was between A and B region. Although Williams, Halcor, Union and Baj-maj had high Ys but they had median amounts in $Y_{p}$ and were cited in C region of scatter plot (as shown in Fig. 4).
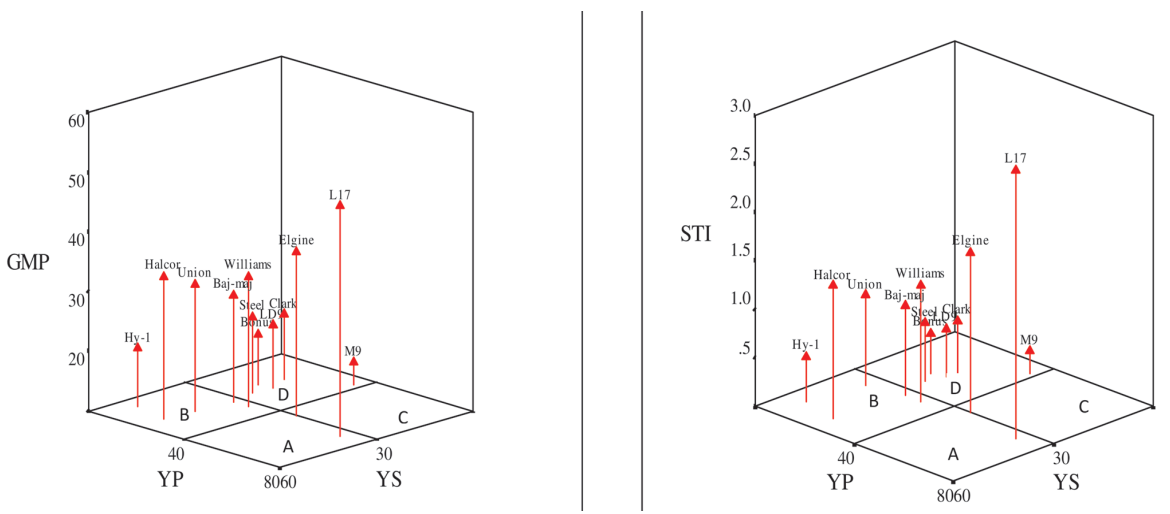

Fig. 4. Display12 soybean cultivars citation based on biologic yield and GMP and STI indices in scatter plot under $30 \mathrm{mM}$ salinity
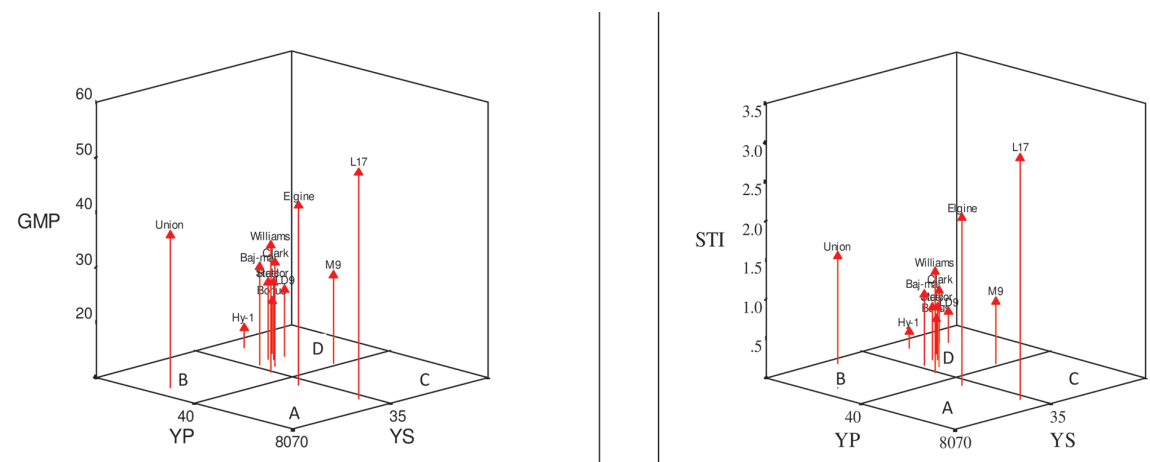

Fig. 5. Display12 soybean cultivars citation based on biologic yield and GMP and STI indices in scatter plot under $60 \mathrm{mM}$ salinity

The cultivars including L17 and Elgine had the high $Y p$ but less than median in $Y s$ under $60 \mathrm{mM}$ salinity and were cited in B region, while Union had the 
high $Y_{s}$ but less than median in $Y_{p}$ so it was cited in $\mathrm{C}$ region (as shown in Fig. 5).
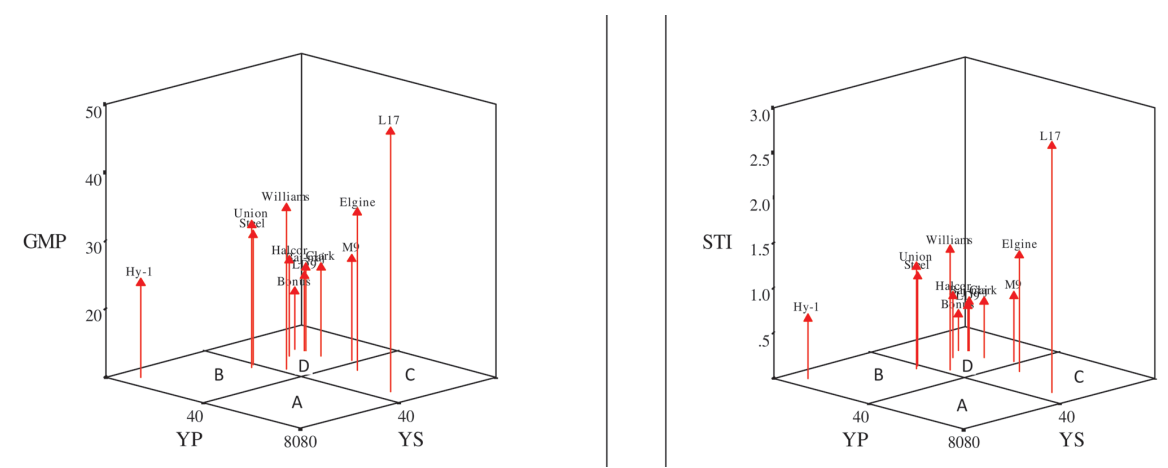

Fig. 6. Display12 soybean cultivars citation based on biologic yield and GMP and STI indices in scatter plot under $30 \mathrm{mM}$ salinity

L17 had the highest Yp but less than median in Ys under $90 \mathrm{mM}$ salinity and was cited in B region. Although Hy-1 had the high amount in Ys but it had low amount in Yp so it was cited in $\mathrm{C}$ region (As shown in Fig. 6).

\section{DISCUSSION AND CONCLUSIONS:}

High genetic variation between studied cultivars on their traits can be a cause for high coefficient variation of evaluated traits.

Considering there was not significant different in A factor (stress), between studied cultivars on the traits such as seed vigor and germination and so dry weight of plumule and biologic yield, It is concluded that these cultivars had almost equal responses to different salinity levels and it's means they had the yield as normal condition.

Considering the percent of variation of traits, it seems soybean seeds had a good adaptability with $60 \mathrm{mM}$ salinity because the most of studied traits had increasing under $60 \mathrm{mM}$ saline water. It's may be salinity had positive effects on radicel growth and some seed character such as vigor and germination but negative effects on plumule growth.

Based on the results, it was concluded that considerable tolerance between studied cultivars in seed germination can be consider in growing stage in further. It can be promising for identification tolerant cultivars to environmental stresses such as salinity and its may some of studied cultivars be suiTable for introduction to cultivation. In a research was reported that some seedling characters such as dry weight of root and stem of soybean was decreased under $80 \mathrm{mili} / \mathrm{mol} \mathrm{NaCl}$ and it was less in tolerant cultivars than others (Velagaleti et al., 1990). The results showed that germination percentage, germination index, and seedling vigor index were decreased under salinity levels from 0 to $15 \mathrm{dS} \times \mathrm{m}^{-1}$ significantly (Kandil et 
al., 2015).On the other hand, it is considerable that basing on the studies, soybean seeds were more tolerant to salinity during germination than in the seedling phase (Khajeh-Hosseini et al., 2002). Other researches reported that salinity stress strongly inhibited seed germination under $12.05 \mathrm{dSm}-1$ (Bahrami and Razmjoo, 2012)

Although based on comparison of means, It was identified L17 and Steel not only had the high seed germination and vigor but also they had dry weight of radicles and biologic yield than others. However, L17 and Elgine were cited in A region (with high potential and stability if yield) of scatter plot based on tolerance indices such as STI and GMP.

\section{ACKNOWLEDGMENTS}

We would like to thank to research and thechnology assistance of Islamic Azad University (Kermanshah Branch) for its collaboration to access seed technology laboratory and Dr. Hamid Reza Babaii (The Scientific Member of Oil Seed Department) from (Seed and Plant Improvement Institute) to provide soybean seed genotypes.

\section{REFERENCES:}

Ahmadvand, G., Soleimani, F., Saadatian, B., and Pouya, M. (2012). Effects of seed priming on germination and emergence traits of two soybean cultivars under salinity stress (Glycine max L.). International Research Journal Applied Basic Sci, 3, 234-241. http://www.irjabs.com/files_site/paperlist/ r_303_121109230551.pdf

Arzani, A. (2001). Breeding for resistance to biotic and abiotic stresses in plants. In: p.2nd, International Zvarian Russia Agriculture and Natural Resources Conference, Feb1-2. 2001. Moscow Timirazer Agriculture Academy, Moscow, Russia. 287-288.

Ashraf, M. and Harris, P.J.C. (2004). Potential biochemical indicators of salinity tolerance in plants. Plant Sci, 166, 3-16. http://www.sciencedirect.com/science/article/pii/S0168945203004679

Bahrami, H. and Razmjoo, J. (2012). Effect of salinity stress $(\mathrm{NaCl})$ on germination and early seedling growth of ten sesame cultivars (Sesamum indicum L.). Inte J of Agric Sci, 2(6), 529-537 http://ijfas.com/wpcontent/uploads/2013/10/895-899.pdf

Basra, A.S. and Basra, R.K. (1997). Mechanisms of environmental stress resistance in plants. Harwood academic publishers. P: 83-111. https://books.google.com/books

Bohnert, H.J., Nelson, D.E. and Jensen, R.G. (1995). Adaptations to environmental stresses. Plant Cell, 7, 1099-1111.

Copeland, L.D. and Mc Donald, M.B. (1985). Seed vigor and vigor tests in: principles of seed science and technology. S2nd Ed. Mc Millian Pub.Co. New York, U.S.A, pp. 121-144.

FAO. Food and Agriculture Organization. http://www.fao.org/home/en/

Fernandez, G.C.J. (1992). Effective selection criteria for assessing plant stress tolerance. In: Adaptation of food crops to temperature and water stress. Kuo, C.G. (ed.). P 257-270, In Proc. Int. Symp., Taipei, Taiwan. 13-18 Aug. 1992. Publ. no. 93-410. Asian VegeTable Researches and Developments Center, Shanhua, Taiwan.

Flowers, T.J., Hajibagheri, M.A. and Clipson, N.J.W. (1986). Halophytes. The Quart. Rev. Biol, 61, 313-337. http://sro.sussex.ac.uk/39088/

Flowers, T.J. and Yeo, A.R. (1995). Breeding for salinity resistance in crop plants: where next? Australian Journal of Plant Physiology, 22, 875-884. http://link.springer.com/article/10.1007\%2Fs11738-997-00390 
Francisco, G., Jhon, L., Jifon, S., Micaela, C. and James, P.S. (2002). Gas exchange, chlorophyll and nutrient contents in relation to $\mathrm{Na}+$ and $\mathrm{Cl}$ - accumulation in sunburst mandarin grafted on different root stocks. Plant Sci, 35, 314.

Glycine max. (2012). Multilingual Multiscript Plant Name Database. Retrieved February 16, 2012. https:// en.wikipedia.org/wiki/Soybean\#

Greenway, H and Munns, R. (1980). Mechanisms of salt tolerance in nonhalophytes. Annual. Review. Plant Physiology. Plant Mol Biol, 31, 149-190. http://www.annualreviews.org/doi/abs/10.1146/ annurev.pp.31.060180.001053

Ikeda, J. (1994). The effect of short term with drawal of $\mathrm{NaCl}$ stress on nodulation of white clover. Plant and soil, 158, 21-23. http://link.springer.com/article/10.1007\%2FBF00007913

International seed testing association Rules. (2013). Germination Sec. Chapter 5, pp. 5 - 44

Jiang, M. and Zhang, J. (2001). Effect of abscisic acid on active oxygen species, anti oxidative defense system and oxidative damage in leaves of maize seedlings. Plant and Cell Physiol, 42, 1265-1273. http:/ www.ncbi.nlm.nih.gov/pubmed/11726712

Kandil, A.A., Sharief, A.E. and Ahmed, Kh.R. (2015). Performance of some soybean Glycine max (L.) Merrill. Cultivars under salinity stress to germination characters. Inte $\mathrm{J}$ of Agron and Agric Res (IJAAR), 6( 3), 48-56. http://www.academia.edu/12026563/Performance ...

Khan, M.A. and Ungar, I.A. (1997). Effect of light, salinity and the thermo period on seed germination of halophytes. Canadian J Bot, 75, 835-841. http://www.nrcresearchpress.com/doi/abs/10.1139/b97-093

Khajeh-Hosseini, M., Powell, A.A., Bingham, I.J., Hussein, M., Powell, A.A. and Bingham, I.J. (2002). Comparison of the seed germination and early seedling growth of soybean (Glycine max (L.) Merrill) in saline conditions. Seed Sci Res, Oxford 12,165-172. http://journals.cambridge.org/action/displayAbstrac

Levitt, J. (1980). Response of plants to environmental stress. Vol. 2. Water, radiation, salt and other stresses. Academic press. New York. pp 607. http://www.sciencemag.org/content/177/4051/786.1.citation

Luo, Q.Y., Yu, B.J., and Liu, Y.L. (2005). Differential sensitivity to chloride and sodium ions in seedlings of Glycine max and Glycine soja under $\mathrm{NaCl}$ stress. J of Plant Physiol, 162, 1003-1012. www.sciencedirect.com/science/article/pii/S0176161705000398

Morrison, M.J., and Xue, A.G. (2007).The influence of seed size on soybean yield in short- season region. Canadian J of Plant Sci, 87, 89-91. http://pubs.aic.ca/doi/pdf/10.4141/P05-209

Tobe, K., Zhang, L., and Omasa, K. (1999). Effect of $\mathrm{NaCl}$ on seed germination of five nonhalophytic species from a Chinese environment. Seed Sci and Technol, 27, 851-863. http://park.itc.u-tokyo.ac.jp/joho/ Omasa/282.pdf

Zhu, J.K. (2001). Plant salt tolerance. Trends in Plant Sci, 6, 66-71. http://www.ncbi.nlm.nih.gov/ pubmed/11173290

Zahran, H.H., and Sprent, J.I. (1986). Effects of sodium chloride and polyethylene glycol on root-hair infection nodulation of vicia faba. L plant by Legominosarum. Planata, 167, 303-309. www.ncbi.nlm.nih.gov/ pubmed/24240297

Velagaleti, R., Marsh, S., Kramer, D., Fleischman, D., and Corbin, J. (1990). Genotypic differences in growth and nitrogen fixation among soybean (Glycin max L. Merr.) Cultivars grown under salt stress. Tropical Agric, 67, 169-177. http://www.cabdirect.org/abstracts/19900735877.htm

Wang, D., and Shannon, M.C. (1999). Emergence and seedling growth of soybean cultivars and maturity groups under salinity. Plant and soil, 214, 117-127. http://link.springer.com/article/10.1023/ A: 1004719420806

Yokoi, S., Bressan, R.A., and Hasegawa, P.M. (2002). Salt stress tolerance of plants. Japan International Research Center For Agricultural Sciences (JIRCAS) Working Report 25-33. http:/l www.plantstress.com/Articles/salinity_m/salinity_m_files/JIRCAS.pdf 